\title{
Status, threats and management actions on the European mink Mustela lutreola (Linnaeus, 1761) in Spain: a review of the studies performed since 1992
}

\author{
Estatus, amenazas y acciones de conservación del visón europeo Mustela lutreola \\ (Linnaeus, 1761) en España: revisión de los estudios realizados desde 1992
}

\section{Mustela lutreola (Linnaeus, 1761) bisoi europarraren estatusa, mehatxuak eta kontserbazio-ekintzak Espainian: 1992tik egindako ikerketen berrikusketa}

\author{
Santiago Palazón ${ }^{1,2 *}$, Yolanda Melero ${ }^{2,3}$ \\ ${ }_{1}^{1}$ Biodiversity and Animal Protection. Department of Agriculture, Livestock, Fish, Food and Wildlife. Generalitat of Catalonia, Spain. \\ ${ }^{2}$ Department of Animal Biology, University of Barcelona, Spain. \\ ${ }^{3}$ School of Biological Sciences, University of Aberdeen, Aberdeen, UK. \\ *Corresponding author: santiago.palazon@gencat.cat
}

\begin{abstract}
There are only three remaining populations of European mink Mustela lutreola (Linnaeus, 1761) in Europe: the Western (Spain and France) the Romanian (Danube Delta) and the Russian population (divided into several subpopulations). The current Spanish population is composed of less than 500 individuals, distributed along 2300 kilometres of watercourses. The presence and the ecological competition with the American mink, the lost of available habitat, water pollution, the isolation and the small size of the population, a high human-induced mortality and the prevalence of the Aleutian mink disease are the main threats faced by the European mink in Spain and other European countries. The National Conservation Strategy aims to ensure the viability of Spanish European mink population by increasing its population size and distribution. However, there first urge is to control the American mink and improve the riparian habitat. Otherwise, European mink could be displaced by the American mink in few years.
\end{abstract}

KEY WORDS: Conservation, distribution, European mink, Spain, threats.

\section{RESUMEN}

En Europa existen tres poblaciones de visón europeo Mustela lutreola (Linnaeus, 1761), la occidental (España y Francia), la rumana (Delta del Danubio) y la rusa (dividida en varias subpoblaciones). La población actual de esta especie en España seguramente está formada por menos de 500 ejemplares, que habitan a lo largo de menos de 2.300 kilómetros de cursos fluviales del centro-norte de la Península lbérica. La presencia y competencia ecológica del visón americano, la destrucción progresiva del hábitat, la contaminación de los sistemas acuáticos, el aislamiento y el pequeño tamaño de la población, la elevada mortalidad por causas antrópicas -atropellos-, y una elevada prevalencia de visones europeos infectados por el virus de Enfermedad Aleutiana del Visón, además de otras enfermedades, son las principales amenazas que acechan a este pequeño mamífero carnívoro en España y también en los otros países europeos donde todavía sobrevive. El objetivo de la Estrategia nacional de conservación de esta especie es asegurar la viabilidad a largo plazo de las poblaciones españolas de visón europeo, incrementando su área de distribución y el número de sus efectivos. Las principales y más urgentes acciones que se deben acometer para conseguir este objetivo son la eliminación y control de las poblaciones de visón americano, y la conservación y recuperación del hábitat para la especie (áreas de refugio y alimentación). En caso contrario, es posible que en pocos años, el visón americano desplace al visón europeo de casi la totalidad de su área actual de distribución.

PALABRAS CLAVE: Amenazas, conservación, distribución, España, visón europeo.

\section{LABURPENA}

Europan Mustela lutreola (Linnaeus, 1761) bisoi europarraren hiru populazio daude: mendebaldekoa (Espainia eta Frantzia), Errumaniakoa (Danubioko delta) eta Errusiakoa (hainbat azpipopulaziotan banatuta). Espezie horren egungo populazioa, Espainian, seguru asko, 500 animaliak baino gutxiagok osatzen dute eta iberiar penintsulako erdialdeko-iparraldeko ibai-bideen 2.300 kilometro baino gutxiagoko azaleran bizi dira. Espainian eta oraindik bizirautea lortu duen Europako beste herrialde batzuetan ugaztun haragijale txiki horrek aurre egin beharreko mehatxu nagusiak honako hauek dira: bisoi amerikarraren presentzia eta lehia ekologikoa, habitata pixkanaka suntsitzea, ur-sistemen kutsadura, isolamendua eta populazioaren neurri txikia, kausa antropikoak (harrapatuta hiltzea) direla eta haien heriotza-tasa altua eta bisoiaren gaixotasun auletiarraren birusak infektatutako Europako bisoien prebalentzia handia eta beste gaixotasun batzuk. Espezie hori kontserbatzeko Estatuko estrategiaren helburua bisoi europarraren Espainiako populazioen epe luzerako bideragarritasuna bermatzea da. Horretarako, banaketa eremua eta efektibo/kide kopurua ugaritu behar dira. Helburu hori lortzeko egin beharreko ekintza nagusiak eta presazkoenak honako hauek dira: bisoi amerikarraren populazioak desagerrarazi eta kontrolatu, eta espezierako habitata suspertu eta kontserbatu (babeseko eta elikatzeko eremuak). Bestela, baliteke urte gutxi barru bisoi amerikarrak bisoi europarra ordezkatzea egungo banaketa eremu ia osoan. 


\section{INTRODUCTION}

The European mink Mustela lutreola (Linnaeus, 1761) is a semiaquatic mustelid with sexual dimorphism (Youngman, 1982, 1990). Morphologically it is characterized by a long thin body with small ears, short legs and a tail half the length of the body. Its fur presents a brown "chocolate" colour with a typical white patch on its lower and upper lips.

The species, endemic from Europe, was extensively distributed through the continent in the 19th century. At that time its distribution covered the Central and Northern Europe, raging from the Atlantic French coast to the Urals Mountains and from the Arctic Polar Circle (Karelia and Finland) to almost the coasts of the Mediterranean and the Black sea (Youngman, 1982, 1990). However, its current distribution is approximately less than $20 \%$ of its historical range (Fig. 1). This reduction was first recorded in Central European countries in the 19th century (Novikov, 1939) although major declines are thought to have taken place by the end of the 20th when it got extinct in 20 different countries (Maran \& Henttonen, 1995; Sidorovich,
2000; Tumanov, 1992). In the last years the decline seems to have slowdown; however remnant populations continue decreasing and it has gone recently extinct in Estonia (Maran, 2006). Currently, only three separated populations remain in the wild: the North-eastern population in Russia (Michaux et al., 2004; Sidorovich, 2000); the Southeastern population in the Danube river delta in Romania (Kranz et al., 2006; Michaux et al., 2004) and Ukraine (de Jongh et al., 2007); and the Western population in Northern Spain and South-western France (Palazón et al., 2002, 2003). The first, the Russian population, ranges from North of European Russia to the Ural Mountains, with a population size lower to 20000 individuals (Tumanov, 1999) and a high decreasing trend from the last two decades (Maran, 2007). The Romanian population was thought to be disappeared but re-found in the decade of the 90s, although its current size is unknown (Gotea \& Kranz, 1999; Kranz et al., 2006). Finally, the Western population, estimated on 1000 mink approximately, is geographically divided by the Pyrenees with little contact between individuals of both sides (Maizeret et al., 2002; Fournier \& Maizeret, 2006). As a result, the species is cu-

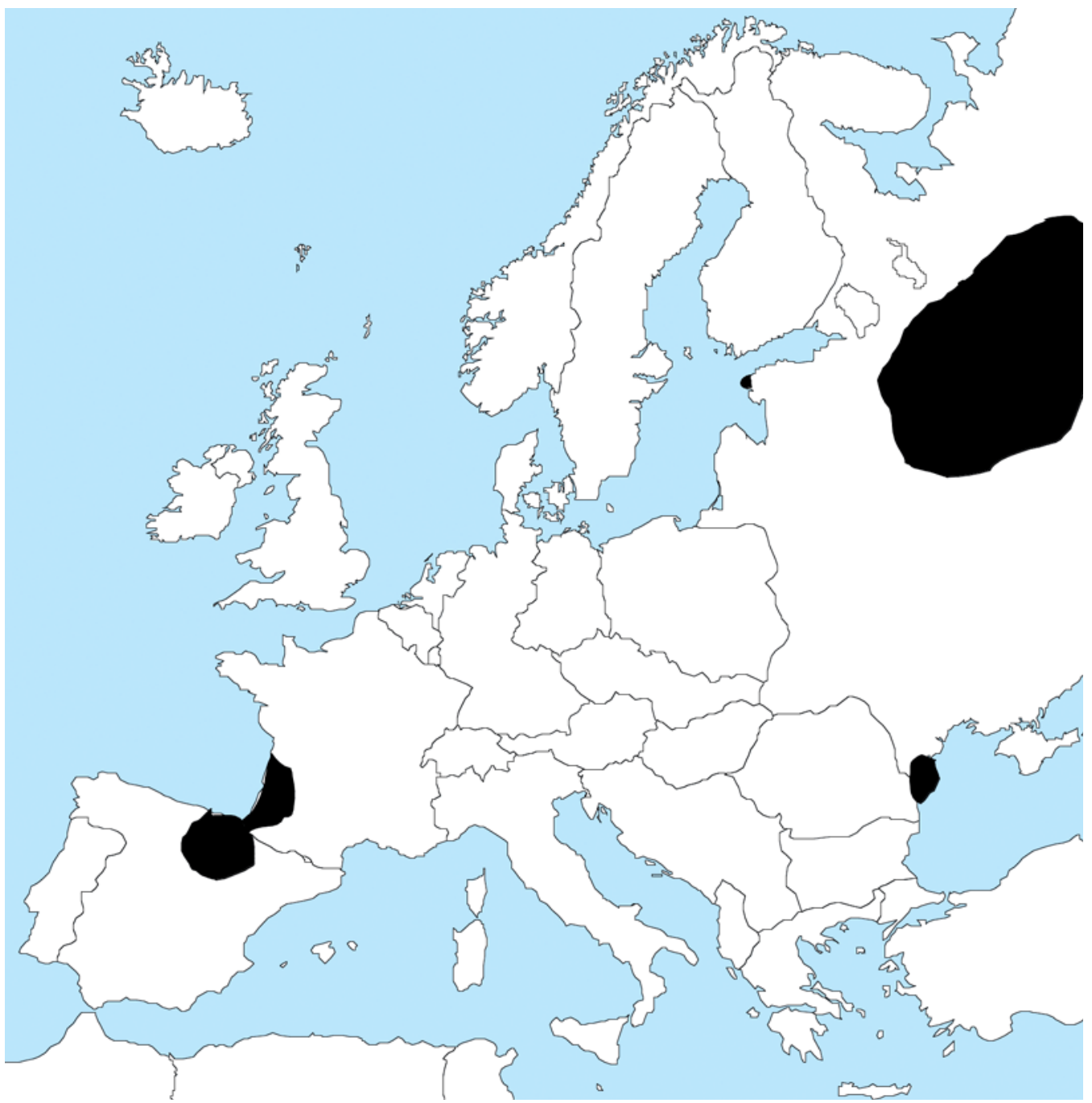

Fig. 1. - Current distribution of European mink in Europe.

Fig. 1. - Distribución actual del visón europeo en Europa. 
rrently the second most threaten mammal in Europe, after the Iberian lynx Lynx pardinus (Temminck, 1827) and one of the most threatened mustelids worldwide. Indeed, the European Union classified it as In Critical Danger (Temple \& Terry, 2007), and it is included in the Catalogue of Directive Habitat (Directive 92/43/CEE, modified by Directive 97/62/CE).

Although the causes of decline of European mink are still in discussion, trends in local populations have been explained by a different combination of the same pool of causes. In general there is a common set of caused implied in the species decline but different combinations of them seem to act in each location. In any location there was a single factor involved in this decline if not an effect of multiple causes. Of them, habitat loss and fragmentation, road casualties, water pollution, trapping and poaching, competition with American mink and diseases as the Aleutian have been singled out as the most important and frequent reasons (Lodé, 2002; Lodé et al., 2001; Mañas et al., 2001; Maran et al., 1998a; Maran \& Henttonen, 1995; Palazón, 2011).

In Spain, the European mink is considered a new comer since its presence is only known since 1955. According to the most feasible hypothesis, the Spanish section was founded by French individuals whose origins come from Central Europe (Rodríguez de Ondarra, 1955, 1963; de Bellefroid, 1999, 2005). The process of its arrival is, however, under discussion with currently two hypotheses: human introduction or natural invasion (Michaux et al., 2004, 2005). Nonetheless, there is a consensus on the fact that the entire Western population (Spain and France) is the result of a "bottleneck" effect that reduced the genetic variability of the population in the area (Michaux et al., 2004; 2005). In Spain, the species is currently distributed along Navarra, La Rioja, Basque Country, Eastern Castilla y León (NW Burgos and North Soria) and Central Aragón (West Zaragoza) (González-Esteban et al., 2001; Palazón et al., 2003; Zabala et al., 2004) (Figure 2). Other smaller fragmented populations have been found in the Cantabric basins. In addition, occasional dispersers have been found in the Western extreme area of Cantabria, Burgos and in the Southeast extreme of Catalonia (RuizOlmo \& Palazón, 1990).

The initial population size in Spain is unknown but it has suffered a decline since the decade of the 90s. Since 2005, this population is classified as In Danger of Extinction and included in the Spanish Terrestrial Mammals Red Book (Palomo et al., 2007). At that time, the "Ministerio de Medio Ambiente y Medio Rural y Marino" launched the Spanish European mink Conservation National Strategy (MAGRAMA, 2009a) which since then works on the conservation of the species in Spain. Moreover, there are parallel regional programs to counteract the population declines in their regions (La Rioja: Recovery Plan 2002, Alava: Management Plan 2003, Bizkaia: Management Plan 2006, Gipuzkoa: Recovery Plan 2006, and two programs in draft phase in Castilla y León and Navarra. Research studies, research studies have been carried out since the first one in 1992 in Navarra (Palazón et al., 2006c) extended later to all the regions where inhabited by the species. Here we expose and resume the results related to the current distribution, status and threats of the European mink population in Spain obtained during these years of studies and the related management actions taken.

\section{MATERIAL AND METHODS}

We did a review of the scientific, grey literature and our own published and unpublished data of the studies carried out on the Spanish population of European mink in Spain.

In all the studies done in Spain since 1992, methodology has been similar with population monitoring mainly via live-trapping with at least one trapping station per $10 \times 10$ km² U.T.M. cells in Navarra, Aragón (Zaragoza and Huesca), La Rioja, Basque Country (Bizkaia, Gipuzkoa and Alava), Castilla and León (Burgos and Soria), Cantabria and Catalonia (Tarragona and Lleida) (Zabala et al., 2001; Palazón et al., 2003, 2006a; Gómez et al., 2011, 2012a). Trapping has been complemented with track and sign surveys and data compilation on road casualties ( $\mathrm{Pa}-$ lazón et al., 2012a) and direct observations. In addition, photographic trapping (González-Esteban et al., 2004) and genetic analysis of scats and hairs have been used (Gómez-Moliner et al., 2004; Zuberogoitia et al., 2012,) in the Basque Country. This information was then used to set the distribution of the population and its temporal trends (e.g. sex-ratio, age-ratio, population growth rate).

Morphological data on the captured individuals was also taken to check the status of the individual, e.g. sex, weight, length, sexual condition and teeth condition; as well as samples of ectoparasites and endoparasites, scat and stomach content and genetic tissue (muscle, liver and hair). Ecological behaviour on activity and space patterns, social interactions, den and resting site use, and habitat selection (Palazón, 1998; Zabala et al., 2003) were also studied by means of radiotracking.

\section{RESULTS AND DISCUSSION}

The studies carried out since 1992 have allowed us to estimate the current population size of European mink in Spain on ca.500 individuals during the prebreeding season (Palazón et al., 2006c; Palazón et al., 2012b). This number can increase after breeding when dispersal occurs but not enough to overcome mortality. The biggest population is located along $250 \mathrm{~km}$ of the upper Ebro and tributaries. However its total distribution covers $2300 \mathrm{~km}$ watercourses mainly low and medium streams with slow water flow, extensive forests, dense riparian vegetation (e.g. brambles, reed-grasses, alder-trees and willows) and good water quality. The population has been found in an altitude range of 0-200m above sea level in Bizkaia, Gipuzkoa and North Navarra (Atlantic basin) and 300-1200m in North Burgos, Álava, La Rioja, North Soria, Central and South Navarra and West Zaragoza (Mediterranean basin) (Palazón, 1998, Palazón et al., 2006b) (Fig. 2). 


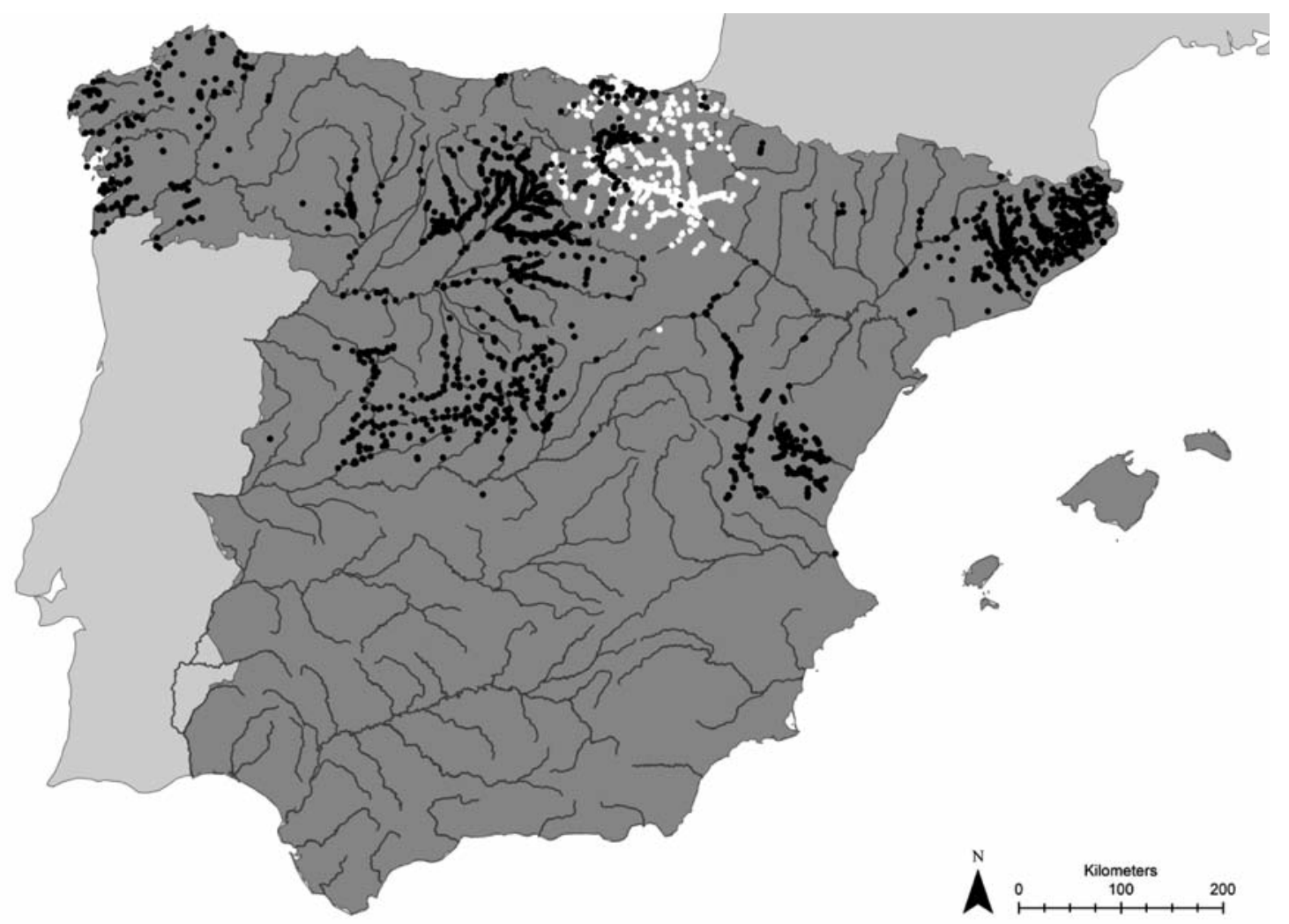

Fig. 2. - Current distribution of European (white points) and American mink (black points) in Spain.

Fig. 2. - Distribución actual del visón europeo (puntos blancos) y el visón americano (puntos negros) en España.

\section{POPULATION THREATS}

The main threats endangering the Spanish population seem to be: presence of American mink Neovison vison (Schreber, 1777); habitat loss, deterioration and fragmentation; low genetic variability and high inbreeding; diseases and epizooties; high human-induced mortality rate; low implementation of current law and normative (Management and Recuperation Plans and National Conservation Strategy); poor scientific knowledge; lack of social awareness.

\section{The American mink}

The non-native invasive American mink has been pointed as one of the most important threats to the European mink in Spain mainly due to the strong ecological competition between both species. American mink is larger, almost twice in weight, and more aggressive than the European mink (Sidorovich \& Macdonald, 2001; Macdonald \& Harrington, 2003; Pôdra et al., 2013). American mink are more successful breeders thanks to their higher reproduction capacity (between 6 and 10 cubs versus 25 in the Spanish European mink population), implantation delay of embryos (up to 30-32 days) (Enders, 1952; Mead, 1989) so the litter can be born in favourable environmental conditions and thus increase its survival probability. The invasive mink also shows a wider trophic niche and it is more adaptable to bad habitat quality in their range of introduction (Woodroffe et al., 1990; Sidorovich, 1992; Maran et al., 1998b; Macdonald et al., 1999). Overall, the higher ecological plasticity of the invasive has provoked displacement and reduction of the European mink (Santulli et al., 2014 under review; Harrington and Macdonald 2008). In addition, American mink has been seen directly attacking and killing several released European mink in Salburua wetland, Alava (Pôdra et al., 2013).

The widespread spread and distribution of American mink in Spain increases its importance as a threat to the European mink which is currently almost surrounded by American mink populations (Fig. 2) (Bonesi \& Palazón, 2007). Moreover, there are still active fur farms of American mink that can't be closed due to the current and next Spanish legislation, although that would be the best solution (Fig. 2). Otherwise, intensive and continuous trapping must be carried out inside and in the area around the farm.

In the Basque Country there are three patches that could merge and increase the threat to the European mink. In Alava, the American mink population is set in the centre of European mink distribution area (Ceña et al., 2003; Carreras et al., 2006), occupying the river Zadorra, its tributaries and associated water reservoirs. Control trapping sessions are done recurrently since 2000 managing to reduce the American mink population to some few 
individuals (Carreras et al., 2006). In Northern Bizkaia, the invasive mink occupies the Cantabric coast and the river Nervion-Ibaizabal (Zuberogoitia \& Zabala, 2003; Zabala, 2006) spreading towards the South and thus, threatening with connecting with the population in Alava. In the last years a trapping project has started with a relative success. American mink in Western Gipuzkoa could also link to the population in Alava and Northern Bizkaia creating a unique population.

The population of American mink in Central Spain is the largest Spanish population (Bravo \& Bueno, 1992; Gómez et al., 2013) with 14 covered provinces (the entire Castilla and León, Cantabria, Cáceres, Madrid, Toledo and Guadalajara). It threats the European mink from Northern Palencia, Burgos and Soria. During the 2000s intensive trapping has been done, especially in Burgos (more than 3000 mink captured). Currently, some American mink have reached the Ebro basin, in northern Burgos and Western-southern La Rioja (Pôdra et al., 2011).

The population in Teruel-Castellón has rapidly spread in the Mediterranean rivers, arriving to Castellón and the Ebro basin in Zaragoza from Teruel. There is a strict trapping control but this population could become an important barrier to the European mink expansion though the Ebro (Jordán et al., 1993) (Gómez et al., $2012 b$ ). The same problems could be provoked by the population in Catalonia which has spread Western from East and Centre Catalonia and thus, with a potential spread to the river Ebro (via Tarragona and Lleida) (RuizOlmo, 1987).

Finally, the French Western Pyrenees population of American mink is a biological barrier for the connection of the Spanish and French sides of the Western European mink population. It is also a source area from American mink since several American mink has been observed arriving to the Basque Country.

In all cases, the objective is to control and potentially eradicate American mink by means of "live-trapping" especially in the areas close to the European mink population and expansion fronts (MAGRAMA-TRAGSA, 2009). Without the control of the invasive mink, the European mink is expected to disappear in 7-10 years $(\mathrm{Pa}$ lazón et al., 2012b).

\section{Habitat loss and fragmentation}

The conservation of good riparian habitat is essential for the conservation of the European mink. Habitat fragmentation and loss by infrastructures increases population fragmentation while reduces connectivity. Destruction and loss of riparian forests, wetlands drainages and water pollution have been very important factors affecting European mink for last 50 years in Spain. Water quality variation by organoclorate compounds-PCBs- and heavy metals caused reproduction and growth problems in mink (López-Martín et al., 1994). There is also the incorrect idea that rivers must be "cleaned", destroying the whole or greatest part of riparian vegetation with a subsequent decrease of refuges and preys and an increase of their vulnerability to predation and non-natural mortality (e.g. hunting).

Currently, compensatory measure has taken action such as the as creation of new wetlands connected with European mink areas and the rehabilitation of much damaged streams. Nonetheless, we also recommend the application of current environmental normative to protect the riparian vegetation and strictly protect the riparian habitat at least $10 \mathrm{~m}$ wide from the watercourse; avoid human intervention (e.g. vegetation removal) during breeding and reproduction seasons (April-August). Works on the river never should be done in both riverbanks concurrently. The study of Calvo-Tomás (2006) could be used to prioritise the protection of areas based on habitat characteristics.

In the last years, many there have been in increase on information on river rehabilitation and technical recommendations on riparian forests that should also be used as management references (CEDEX, 2005).

\section{Genetic problems}

The bottleneck effect occurred during the formation of the Western population of European mink, together with its small size and the isolation between the French and the Spanish areas has caused low genetic variability in both areas (Michaux et al., 2005). Populations with low genetic variability are more susceptible to inbreeding, genetic drift and extinction by accidental or random process (genetic drift). In addition, hybridization with sympatric European polecat has also been detected in Spain Tumanov \& Abramov, 2002; (Cabria et al., 2011) but in very low numbers of maximum one per year (Melero et al. in prep).

A potential solution could be to translocate European mink from Russia (where the species presents higher genetic variability) into Spain. However, experts decided not to translocate individuals so to keep populations as different genetic units. Moreover, translocate individuals could also be a source of new endoparasites and diseases, or present adaptability problems.

\section{Diseases and epizooties}

The presence of American mink in the wild has spread the Aleutian Mink Disease (ADV) parvovirus, pathology without preventive or curative treatment. The virus causes physiological malfunctions, immunological problems, sterility, fertility decrease and spontaneous miscarriages with cases of direct death. Moreover, mink infected by ADV are more susceptible to secondary infections. The prevalence of this disease is very high in the Spanish population of European mink (30\%; $n=79$ ) (Mañas et al., 2001, 2003)

In the last years, some mink were also detected with Canine Distemper in Navarra (Gobierno de NavarraGAVRN, 2005) and Aragon (Gomez et al., 2012a).

The presence of ectoparasites (Ixodes hexagonus Leach 1815 and Ixodes acuminatus Neumann 1901) (Ro- 
dríguez-Refojos et al., 2006) and endoparasites (trematodae, flukes, cestodae, nematodae and acantocefalae) can cause diseases in the skull, liver, lungs and intestines (Torres et al., 2003, 2006a, 2006b; Shimalov \& Shimalov et al., 1993; Zhemchuzina \& Tumanov, 2006). They can reduce the immunological activity of mink, decrease the female fertility and the cub survival, and stimulate the development of bacterial and viral diseases.

Sanitary and veterinary monitoring should be continued to better know the situation and impact of the ADV and the Canine Distemper. Up to date, there is not treatment for any of these diseases or those caused by endoparasites.

\section{Human-induced mortality}

There is a high non-natural mortality, mainly caused by road traffic, but also by drowns and crushing caused by infrastructures and works on riparian and aquatic ecosystems. In 1970s the first European mink killed by road casualty record was confirmed (Palazón \& Ruiz-Olmo, 1997; Palazón, 1998; Palazón et al., 2012a) but it became the first cause of human-induced mortality in the 1990s and 2000s (Fig. 3) (Palazón et al., 2012a). Mortality due to road kills increases during mating and dispersal season when mink move more actively (Palazón et al., 2012a).

Other sorts of human-induced mortality include captures and shots (especially important before the effective legal protection of 1989, and currently casualties due to channels, water power stations or construction works among other of difficult quantification.

As previously suggested in Palazón et al. (2012a) road black points should be located, registered and marked accordingly or avoided via lower fauna passages. Several studies on this subject are being carried out in $\mathrm{La}$ Rioja (Gobierno La Rioja-TRAGSA, 2008a, 2008b, 2008c) and Navarra (Forcada, 2008). In the first black points have been pointed and corrected to avoid road casualties by passageways. In Navarra, some black points have been prepared with passageways complemented with posterior monitoring. In La Rioja, the most dangerous points and streams for European mink were studied, and several corrections were designed.

Presence and conservation of European mink should be considered when planning the construction of new infrastructures (e.g. roads, highways, channels, bridges, power station or dams). River permeability should be continued to disruption of mink territories to avoid mink confronting risks. Population monitoring after infrastructure changes is recommendable to track the species mortality and its causes (Rosell \& Velasco Ribes, 1999; Hervás et al., 2006).

\section{CURRENT DIRECT MANAGEMENT ACTIONS}

\section{Captive Breeding Program}

In 2008, a Captive Breeding and ex situ Conservation Program was approved in Spain, although it was running since 2004 when the first European mink founders were captured (MAGRAMA, 2009b). The main objective is to have a stock of the Spanish European mink population to counteract potential catastrophes in the wild population via reinforcements via reintroductions (MAGRAMA-TRAGSA, 2010). Studies on European mink behaviour, reproduction and adaptation have been carried out in parallel.

A total of nine mink captured in 2004 and two more in 2005 mink were captured and taken as founders for the program. Overall, 108 mink have born between 2005 and 2012 from 30 original litters with an average of 2.92 cubs per litter $(S D=1.09)$ and a sex-ratio of 1:1 (49 males and 50 females) ( $P>0.05)$. Currently, there are 50 mink in captivity in ten breeding centres (Podra \& Pala-

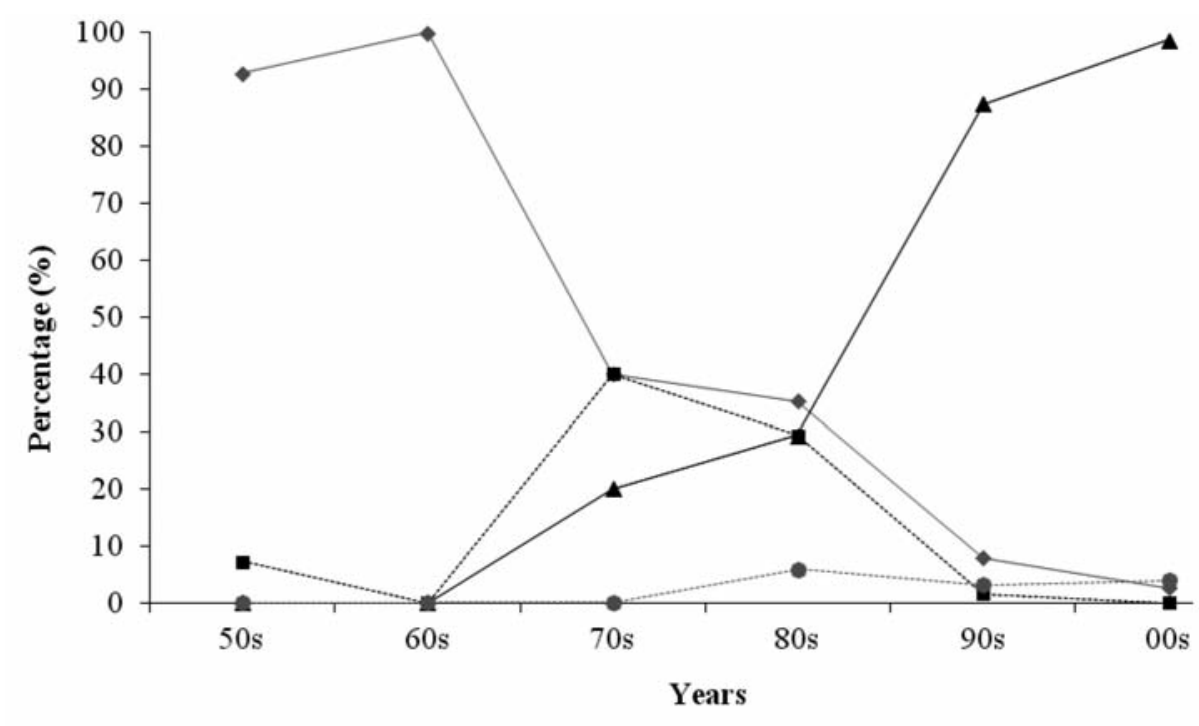

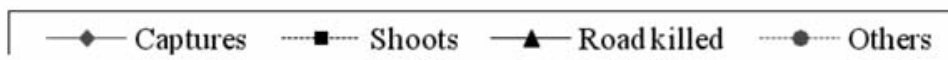

Fig. 3. - Temporal variation of humaninduced mortality in the European mink in Spain.

Fig. 3. - Variación temporal de la mortalidad por causas antrópicas del visón europeo en España. 
zón, 2012). Life expectancy in the wild ranged between 2-3 years although there were few cases of mink older than 5 years (Palazón et al., 2013)

Eight captive bred mink (one male and seven female) were released in 2008; 16 (eight males and eight females) in 2009 and three females more in 2010. All mink were released in in Salburua (Álava) in 2008, 2009 and monitored to evaluate their adaptation to the wild (MAGRAMA-TRAGSA, 2010). Main problem in the wild was predation by American mink, dogs, feral cats and raptors (MAGRAMA-TRAGSA, 2010; Podra et al., 2013). Males survived more than females, and mink released by means of pre-release facilities were a higher survival (MAGRAMA-TRAGSA, 2010)

\section{In situ Conservation Management}

Several LIFE projects have been and are carried out in Spain: Castilla and Leon (Burgos and Soria) (Temiño, 2005), La Rioja and Alava (2001-2004), Catalonia (20022005) and Navarra (2005-2008) and (2010-2014). There is a Working Group of European mink, created in 1999 and coordinated by the Department of Agriculture and Environment. In 2005 the European mink Conservation National Strategy was accepted (MAGRAMA, 2009a) with the implementation of the American mink control and eradication Plan as first action of the Strategy (MAGRAMA-TRAGSA, 2009). Moreover, several Recuperation (La Rioja) and Management (Alava, Gipuzkoa and Bizkaia) Plans of European mink were approved in the decade of the 2000s.

Nonetheless, the Spanish political situation complicates the collaboration and joined efforts between the different regions were European mink is present. In spite of the narrow distribution and the low number of mink, its population is divided in five administrative regions (Autonomous Communities) with different local administrations (local governments). Indeed, in the case of Basque country, there is even a secondary division with three territories each with its own legislation and management guidelines.

\section{CONCLUSIONS}

The Spanish population of European mink, as well as other populations of the species, could benefit from a more exhaustive monitoring of both the species and its competitor the American mink. This should include a deeper research on the species and management actions motivated by research findings. The main effort should be focused on improving the current monitoring methodologies (e.g. live trapping or non-invasive genetic monitoring) so to increase our knowledge on the population and the accuracy of the findings. Research should be leaded by a collaborative approach where current local databases are all linked and available for the local and national administrations; information should be interchanged between them and collaboration could be open to international researchers and managers. A better knowledge on the species in general and on the population on particular could lead more adapted management actions following an active-adaptive ma- nagement approach where actions are guided by the latest findings on the population (e.g. latest status and distribution, migration waves and their directions). Nonetheless, management actions should be applied to the entire distribution of the population via coordination of the different local administrations. Under this aegis, a coordination framework could be created between the local administrations and the National Department of Agriculture and Environment, composed by a head technitian and of at least one representative of each local administration where European mink is present or from where there could be a threat (e.g. the spread of the American mink from Catalonia and Teruel). Overall, administrations, institutions and people must work in the same way and direction or the European mink will disappear from Spain in the next years.

\section{ACKNOWLEDGEMENTS}

We are grateful to the people who have collaborated in the different studies carried out for all these years. We are also grateful to the local and national administrations, especially to the technicians from La Rioja, Alava, Navarra, Castilla y León, Gipuzkoa, Bizkaia, Cantabria, Aragón Valencia, Catalonia, the Spanish Department of Agriculture and Environment, TRAGSA, Hydrographical Confederation of Ebro river, European Mink Association, ACS-Dragados, University of Barcelona, University of Basque Country and the European Union (Life Projects). Especial thanks to Asun Gómez, Madis Podra, César Aguilar, Sonia Oreca, Sisco Mañas, Vicky Asensio, Mirenka Ferrer, Javier López de Luzuriaga, Javier Pinedo, Haizea Aguirre, Rebeca Pérez de Eribe, Giulia SantulliSanzo, Mireia Plaza, Karla García, Eva Lahoz, Elena Rafart and Mikel Arenas.

\section{BIBLIOGRAPHY}

Bonesi, L., Palazón, S. 2007. The American Mink in Europe: status, impacts, and control. Biol. Conserv. 134: 470-483.

Braun, A.J. 1990. The European mink in France: past and present. Mustelid \& Viverrid Conservation 3: 5-8.

Bravo, C., Bueno, F. 1992. Nuevos datos sobre la distribución del visón americano (Mustela vison Schreber) en la España Central. Ecología 6: 161-164.

Cabria, M.T., Michaux, J.R., Gómez-Moliner, B.J., Skumatov, D. Maran, T., Fournier, P., López de Luzuriaga, J., Zardoya, R. 2011. Bayesian analysis of hybridization and introgression between the endangered european mink (Mustela lutreola) and the polecat (Mustela putorius). Mol. Ecol. 20: 1176-1190.

Calvo-Tomás, A. 2006. Caracterización del hábitat de la distribución real y potencial del visón europeo (Mustela lutreola) en la cuenca hidrográfica del Ebro: Metodología de caracterización. Naturaleza aragonesa 17: 65-71.

Carreras, J., López de Luzuriaga, J., Gómez, A., Ceña, A., Pinedo, J., Lobo, L., Ceña, J.C. 2006. Substitution of the European mink (Mustela lutreola) for the American mink (Mustela vison) in the Zadorra river basin (Basque country, Spain). Proceedings of the International Congress on the Conservation of European mink (Mustela lutreola). Logroño: 301-302. 
CEDEX. 2005. /l Curso sobre ecología fluvial y restauración de ríos y riberas. Madrid.

Ceña, A., Ceña, J.C., Lobo, L. 2003. Sustitución del visón europeo (Mustela lutreola) por el visón americano (Mustela vison) en el municipio de Vitoria-Gasteiz. Galemys 15: 131-143.

De Bellefroid, M.N. 1999. Étude biogeographique de l'evolution de la population de vison européen, Mustela lutreola, en France. Statut, répartition, écologie, facteurs de déclin et stratégie de conservation pour l'espèce. Thèse de diplome doctoral de recherches. Université de Rennes. Rennes.

De Bellefroid, M.N., Rosoux, R. 2005. Le Vison d'Europe. Belin Éveil Nature. Paris.

De Jongh, A.W.J.J., Tokar, G.A., Matvyeyev, A.S., et al. 2007. European mink (Mustela lutreola) still surviving in Ukrainian deltas of the Danube and Dniester. Lutra 50: 49-52.

Enders, R.K. 1952. Reproduction in the mink. Proc. Amer. Phil. Soc. 96: 691-755.

Forcada, J. 2008. Adecuación de infraestructuras viarias existentes en hábitats de alta calidad para visón europeo. Grupo de Trabajo de Fragmentación de Hábitats causada por Infraestructuras de Transporte, Ministerio de Medio Ambiente y Medio Rural y Marino. Madrid.

Fournier, P., Maizeret, C. 2006. Status and conservation of the European mink (Mustela lutreola) in France. Proceedings of the International Congress on the Conservation of European mink (Mustela lutreola). Logroño: 95-102.

Gobierno de Navarra-GAVRN. 2005. Proyecto LIFE: Gestión Ecosistémica de Ríos con Visón Europeo. Pamplona.

Gobierno de La Rioja-TRAGSA. 2008a. Manual técnico de gestión para reducir la probabilidad de atropellos de visón europeo en la Comunidad Autónoma de La Rioja. Logroño.

Gobierno de La Rioja-TRAGSA. 2008b. Manual técnico de gestión para Centrales Hidroeléctricas en zonas con presencia de visón europeo en la Comunidad Autónoma de La Rioja. Logroño.

Gobierno de La Rioja-TRAGSA. 2008c. Manual técnico de gestión para Obras Hidráulicas en zonas con presencia de visón europeo en la Comunidad Autónoma de La Rioja. Logroño.

Gómez, A., Oreca, S., Pôdra, M., Sanz, B., Palazón, S. 2011. Expansión del visón europeo Mustela lutreola (Linnaeus, 1761) hacia el este de su área de distribución en España: primeros datos en Aragón. Galemys 23 (NE): 37-46.

Gómez, A., Oreca, S., Sanz, P., Pérez, M., Palazón, S., Pôdra, M. 2012a. Monitorización del visón europeo en Aragón. Gobierno de Aragón-TRAGSA. Zaragoza.

Gómez, A., Oreca, S., Sanz, P., Dregorio, A., Egido, D., Barroso, S., Palazón, S., Pôdra, M. 2012b. Control del visón americano (Neovison vison) en las provincias de Teruel y Zaragoza. Gobierno de Aragón-TRAGSA. Zaragoza.

Gómez, A., Pôdra, M., Pérez, M., Ferrer, M., Palazón, S., González, L.M. 2013. Cambios en la distribución y el estado actual del visón americano (Neovison vison) en España. XI Congreso de la Sociedad Española para la Conservación y Estudio de los Mamíferos. Avilés. 5-8 Diciembre 2013

Gómez-Moliner, B.J., Cabría, M., Rubines, J., Garín, I., Madeira, M.J., Elejalde, A., Aihartza, J., Fournier, P., Palazón, S. 2004. PCRRFLP identification of mustelid species: European mink (Mustela lutreola), American mink (M. vison) and polecat (M. putorius) by analysis of excremental DNA. J. Zool. 262 (3): 311-316.
González-Esteban, J., Villate, I., Irizar, I. 2001. Área de distribución y valoración del estado de las poblaciones del visón europeo en la Comunidad Autónoma del País Vasco. Gobierno Vasco. Bilbao.

González-Esteban, J., Villate, I., Irizar, I. 2004. Assesing camera traps for surveying the European mink Mustela lutreola (Linnaeus, 1761) distribution. EJWR 50: 33-36.

Gotea, V., Kranz, A. 1999. The European mink in the Danube Delta. Small Carniv. Conserv. 21: 23-25.

Harrington, L.A., Macdonald, D.W. 2008. Spatial and Temporal Relationships between Invasive American Mink and Native European Polecats in the Southern United Kingdom. J. Mammal. 89(4): 991-1000.

Hervás, I., Suárez, F., Mata, C., Herranz, J., Malo, J.E. 2006. Pasos de fauna para vertebrados. Minimización y seguimiento del efecto barrera de las vías de comunicación. Centro de Estudios y Experimentación de Obras Públicas, CEDEX. Madrid.

Jordán, G., Marco, G., Gortázar, C. Calvete, C. 1993. Distribución del visón americano (Mustela vison) en la Comunidad Autónoma de Aragón. Resúmenes I Jornadas Sociedad Española Conservación y Estudio de los Mamíferos. Málaga: 41.

Kranz, A., Toman, A., Polednikova, K., Polednik, L., Kiss, J.B 2006. The European mink in the Romanian Danube Delta and ad jacent lagoon complexes: distribution, status and conservation priorities. Proceedings of the International Congress on the Con servation of European mink (Mustela lutreola). Logroño: 103-112.

Lodé, T. 2002. An endangered species as an indicator of freshwater quality: fractal diagnosis of fragmentation within a European mink Mustela lutreola, population. Arch. Hydrobiol. 155 163-176.

Lodé, T. Cormier, J.P., Le Jacques, D. 2001. Decline in endangered species as an indication of anthropic pressures: the case of European mink Mustela lutreola Western population. Environ. Manag. 28: 221-227.

López-Martín, J.M., Ruiz-Olmo, J., Palazón, S. 1994. Organochlorine Residue Levels in the European mink (Mustela lutreola) in Northern Spain. Ambio 23 (4-5): 294-295.

Macdonald, D.W., Barreto, G.R., Ferreras, P., Kirk, B., Rushton, S. Yamaguchi, N., Strachan, R., 1999. The impact of American mink Mustela vison, as predators of native species in British freshwater systems. Advances in Vertebrate Pest Management. Filander-Verlag, Furth: 5-24.

Macdonald, D.W., Harrington, L.A., 2003. The American mink: the triumph and tragedy of adaptation out of context. New Zealand J. Zool. 30: 421-441. Disponible en web: http://www.tandfonline.com/doi/pdf/10.1080/03014223.2003.9518350.

Maizeret, C., Migot, P., Galineau, H., Grisser, P., Lodé, T. 1998 Repartition et habitats du vison d'Europe (Mustela lutreola) en France. Arvicola, Actes « Amiens 97». Amiens: 67-72.

Maizeret, C., Migot, Rosoux, R., Chusseau, J.P., Gatelier, T., Maurin, H., Fournier-Chambrillon, C. 2002. The distribution of the European mink (Mustela lutreola) in France: towards a short extinction? Mammalia 66: 525-532.

Mañas, S., Ceña, J. C., Ruiz-Olmo, J., Palazón, S., Domingo, M., Wolfinbarger, J. B., Bloom, M. E. 2001. Aleutian mink disease parvovirus in wild riparian carnivores in Spain. J. Wild. Dis. 37(1) 138-144.

Mañas, S. Ceña, J. C. Palazón, S., Ruiz-Olmo, J., Ceña, A., Domingo, M., Bloom, M. E. 2003. El visón europeo y el parvovirus de la enfermedad aleutiana. Quercus 203: 18-21.

Maran, T., 2006. Conservation of the European mink in Estonia: an update 2001-2003. International Conference on the Conservation of European Mink (Mustela lutreola). Logroño: 131-142. 
Maran, T. 2007. Conservation biology of the European mink, Mustela lutreola (Linnaeus 1761): decline and causes of extinction. PhD Thesis. Tallin University. Tallin.

Maran, T., Henttonen, H. 1995. Why is the European mink, (Mustela lutreola) disappearing? - A review of the process and hypotheses. Ann. Zool. Fennici 32: 47-54.

Maran, T., Macdonald, D.W., Kruuk, H., Sidorovich, V., Rozhnov, V.V. 1998a. The continuing decline of the European mink, Mustela lutreola: evidence for the intraguild aggression hypothesis. In: $\mathrm{Be}$ haviour and Ecology of Riparian Mammals: 297-324. Cambridge.

Maran, T., Kruuk, H., Macdonald, D.W., Polma, M., 1998b. Diet of two species of mink in Estonia: displacement of Mustela lutreola by Mustela vison. J. Zool. (Lond.) 245: 218-222.

MAGRAMA. 2009a. Estrategia para la conservación del visón europeo (Mustela lutreola) en España. Ministerio de Medio Ambiente y Medio Rural y Marino. Madrid.

MAGRAMA, 2009b. Programa de conservación ex situ del visón europeo (Mustela lutreola) en España. Ministerio de Medio Ambiente y Medio Rural y Marino. Madrid.

MAGRAMA-TRAGSA, 2009. Plan de prevención, control y erradicación del visón americano en España. Resultados 2009. Madrid.

MAGRAMA-TRAGSA, 2010. Reintroducción y Refuerzo poblacional del visón europeo (Mustela lutreola). Madrid.

Mead, R.A. 1989. Reproduction in mustelids. In: Conservation biology and the black-footed ferret. U.S. Seal, E.T. Thorne, M.A. Bogan, S.H. Anderson (Ed.): 124-137. Yale University Press. New Haven and London.

Melero, Y., Palazón, S., Gómez A., Podra, M., Gosàlbez, J. Note on the hybridisation frequency between European mink and polecat in Spain. In prep.

Michaux, J,R L, Libois, R., Davidson, A. Chevret, P., Rosoux, R 2004. Is the western population of the European mink (Mustela lutreola) a distinct management unit for conservation? Biol. Conserv. 115: 357-367.

Michaux, J.R., Hardy, O.J., Justy, F., Fournier, P., Kranz, A., Cabria, M., Davidson, A., Rosoux, R., Libois, R. 2005. Conservation genetics and population history of the threatened European mink Mustela lutreola, with an emphasis on the west European population. Mol. Ecol. 14: 2373-2388

Novikov, G.A. 1939. The European mink. Izd. Leningradskogo Gos. Univ. Leningrado.

Palazón, S. 1998. Distribución, morfología y ecología del visón europeo (Mustela lutreola L. 1761) en la Península Ibérica. Tesis doctoral. Universidad de Barcelona. Barcelona.

Palazón, S. 2011. El visó europeu (Mustela lutreola) a Espanya: situació, biologia, ecologia i conservació. Atzavara 20: 107-116.

Palazón, S. 2012. Situació i control del visó americà a Catalunya. Generalitat de Catalunya. Barcelona.

Palazón, S., Ruiz-Olmo, J. 1997. El visón europeo (Mustela lutreola) y el visón americano (Mustela vison) en España. Colección Técnica. Ministerio de Medio Ambiente. Madrid.

Palazón, S. Ceña, J.C., Mañas, S., Ceña, A., Ruiz-Olmo, J. 2002. Current distribution and status of the European mink (Mustela lutreola L., 1761) in Spain. Small Carniv. Conserv. 26: 9-11.

Palazón, S., Ruiz-Olmo, J., Gosálbez, J., Gómez, A., Ceña, J.C. Ceña, A. 2003. Trends in distribution of the European mink (Mustela lutreola L., 1761) in Spain: 1950-1999. Mammalia 67(4): 473-484.
Palazón, S., Ruiz-Olmo, J., Gosálbez, J., Arjona, L., Batet, T., Melero, Y., Gómez, A., Rafart, E. 2006a. Trapping of European mink (Mustela lutreola) and other carnivores in Spain. Proceedings of the International Congress on the Conservation of European mink (Mustela lutreola). Logroño: 143-150

Palazón, S., Ruiz-Olmo, J., Gosálbez, J. 2006b. Habitat use and selection of European mink (Mustela lutreola) in Navarre and La Rioja, northern Spain. Proceedings of the International Congress on the Conservation of European mink (Mustela lutreola). Logroño: 157-166.

Palazón, S., Ruiz-Olmo, J., Gosálbez, J. 2006c. How many European minks (Mustela lutreola) inhabits in the Navarre rivers, Northern Spain. Proceedings of the International Congress on the Conservation of European mink (Mustela lutreola). Logroño: 179-186.

Palazón S. Melero, Y. Gómez, A., López de Luzuriaga, J., Pôdra M. \& Gosálbez, J. 2012a. Causes and patterns of human-induced mortality in the Critically Endangered European mink Mustela Iutreola in Spain. Oryx 46: 614-616.

Palazón, S., Santulli-Sanzo, G., Plaza, M., Melero, Y., Gosálbez, J. 2012b. Análisis de la viabilidad de la población española de visón europeo (Mustela lutreola). Aplicación del programa VORTEX 9.99b. Asociación Visón Europeo-IMEDEA, CSIC-TRAGSA. Barcelona.

Palazón, S., Gómez, A., Pôdra, M., Oreca, S., Ferrer, M. 2013. Estudio Poblacional del visón europeo (Mustela lutreola) en La Rioja, Álava y Burgos: Río Ebro y Río Najerilla (tramo bajo): 2012. MAGRAMA-TRAGSA. Madrid.

Palomo, L. J., Gisbert, J., Blanco, J.C. 2007. Atlas y Libro Rojo de los Mamíferos Terrestres de España. Dirección General para la Biodiversidad-SECEM-SECEMU, Madrid.

Pôdra, M., Sanz, P., Oreca, S., Gómez, A., Aguilar, C., Lopo, L. 2011. Monitorización de la población de visón europeo (Mustela lutreola) en La Rioja. Gobierno de La Rioja-TRAGSA. Logroño.

Pôdra, M., Palazón, S. 2012. Informe técnico sobre el estado actual del programa ex situ de visón europeo en la Península Ibérica: Informe de actividades. Asociación Visón Europeo TRAGSATEC - Ministerio de Agricultura, Alimentación y Medio Ambiente. Barcelona.

Pôdra, M., Gómez, A., Palazón, S. 2013. Do American mink kill European mink? Cautionary message for future recovery efforts. EJWR 59: 431-440

Rodríguez de Ondarra, P.M. 1955. Hallazgo, en Guipúzcoa, de un mamífero no citado en la "Fauna Ibérica" de Cabrera. Munibe 7(4): 201-207.

Rodríguez de Ondarra, P.M. 1963. Nuevos datos sobre el visón en España. Munibe 15: 103-110.

Rodríguez-Refojos C., Zabala J., Zuberogoitia I., Barral, M. 2006 Ectoparasitic charge of small carnivores and its sanitary implications. Small Carniv. Conserv. 35: 33-34.

Rosell, C., Velasco Rivas, J. 1999. Manual de prevenció i correcció dels impactes de les infraestructures viàries sobre la fauna. Documents dels Quaderns de medi ambient, núm. 4. Departament de Medi Ambient. Generalitat de Catalunya. Barcelona.

Ruiz-Olmo, J. 1987. El visón americano, Mustela vison Schreber 1777 (Mammalia, Mustelidae), en Cataluña, NE de la Península Ibérica. Doñana Acta Vertebrata 14: 142-145.

Ruiz-Olmo, J., Palazón, S. 1990. Occurrence of European mink (Mustela lutreola) in Catalonia. Miscellania Zool. 14: 249-253.

Santulli, G., Palazón, S., Melero, Y., Gómez, A., Podra, M., Gosálbez, J., Lambin, X. 2014. Multi-seasons occupancy analysis reveals large scale competitive exclusion of the critically endangered European mink by the invasive non-native American mink in Spain. Biol. Conserv. 176: 21-29. 
Shimalov, V.T., Sidorovich, V.E, Shimalov, V.V. 1993. Helminths of mustelids (Mustelidae) inhabiting the ponds of Belarus. Proceedings of the Academy of Sciences of Belarus, 4. Minsk: 96-101.

Shimalov, V.T., Shimalov, V.V. 2006. The helminths as a cause of a negative effect on the European mink in Belarus. Proceedings of the International Congress on the Conservation of European mink (Mustela lutreola). Logroño: 225-230.

Sidorovich, V.E., 1992. Comparative analysis of the diets of European mink (Mustela luteola) American mink (M. vison) and Polecat (M. putorius) in Byelorussia. Small Carniv. Conserv. 6: 2-4

Sidorovich, V.E. 2000. The on-going decline of riparian mustelids (European mink, Mustela lutreola, polecat, Mustela putorius, and stoat, Mustela erminea) in eastern Europe: a review of the results to date and an hypothesis. Mustelids a Mod. World. Manag. Conserv. Asp. Small Carniv. Hum. Interact. Leiden: 295-319.

Sidorovich, V., Macdonald, D.W., 2001. Density dynamics and changes in habitat use by the European mink and other native mustelids in connection with the American mink expansion in Belarus. Neth. J. Zool. 51: 107-126.

Temiño, C. 2005. La conservación del visón europeo en Castilla y León. Gama S.L.; Junta de Castilla y León. Burgos.

Temple, H., Terry, A.C. 2007. The Status and Distribution of European Mammals. Office for Official Publications of the European Communities. Luxembourg.

Torres, J., Mañas, S., Palazón, S., Ceña, J.C., Miquel, F., Feliu, C. 2003. Helminth parasites of Mustela lutreola (Linnaeus, 1761) and M. vison (Schreber, 1777) in Spain. Acta Parasitologica 48: 55-59

Torres, J., Mañas, S., Miquel, J., Palazón, S., Ceña, J.C., Feliu, C. 2006a. On the parasite fauna of Mustela lutreola (Linnaeus, 1761) in Spain. Possible cross transmission of some helminths with neighbouring Spanish populations of Mustela vison (Schreber, 1777) and Mustela putorius (Linnaeus, 1758). Proceedings of the International Congress on the Conservation of European mink (Mustela lutreola). Logroño: 363-364.

Torres, J., Mañas, S., Miquel, J., Palazón, S., Ceña, J.C., Feliu C. 2006b. Considerations about the usefulness of coprological methods with regard to necropsy of endangered mammals. The case of Mustela lutreola (Linnaeus, 1761) in Spain. Proceedings of the International Congress on the Conservation of European mink (Mustela lutreola). Logroño: 361-362.

Tumanov, I.L. 1992. The number of European mink (Mustela lutreola L.) in the eastern area and its relation to American mink. Semiaquatische Säugetiere (Osnabruck): 329-336.
Tumanov, I.L. 1999. The modern state of European mink (Mustela lutreola L.) populations. Small Carniv. Conserv. 21: 9-11.

Tumanov, I.L., Abramov, A.V. 2002. A study of the hybrids between the European mink Mustela lutreola and the polecat M. putorius. Small Carniv. Conserv. 27: 29-31.

Woodroffe, G.L., Lawton, J.H., Davidson, W.L., 1990. The impact of feral mink Mustela vison on water voles Arvicola terrestris in the North Yorkshire Moors National Park. Biol. Conserv. 51: 49-62.

Youngman, P.M. 1982. Distribution and systematics of the European mink Mustela lutreola Linneus 1761. Acta Zool. Fenn. 166:1-48.

Youngman, P.M. 1990. Mustela lutreola (Linnaeus, 1761). Mamm. Species 362: 1-3.

Zabala, J. 2006. Distribution and spatial ecology of semi-aquatic mustelids (Carnivora: Mustelidae) in Biscay. PhD Thesis. Basque Country University. Leioa, Bilbao.

Zabala, J., Zuberogoitia, I., Garin, I., Aihartza, J. 2001. Small carnivore trappability: Seasonal changes and mortality. A case study on European mink Mustela lutreola and spotted genet Genetta genetta. Small Carniv. Conserv. 25: 9-11.

Zabala, J., Zuberogoitia, I., Garín, I., Aihartza, J. 2003. Landscape features in the habitat selection of European mink (Mustela lutreola) in south-western Europe. J. Zool. 260: 415-421.

Zabala, J., Zuberogoitia, I., Martínez-Climent, J.A. 2004. The historical and current distribution of the Iberian population of European mink (Mustela lutreola). Lutra 47: 101-112.

Zhemchuzina, A., Tumanov, I. 2006. The influence of infection by nematodes on the physiological state and the population number of minks (Mustela lutreola, M. vison). Proceedings of the International Congress on the Conservation of European mink (Mustela lutreola). Logroño: 365-366.

Zuberogoitia, I., Zabala, J. 2003. El visón europeo en Vizcaya Quercus 209: 24-27.

Zuberogoitia, I., Zalewska, H., Zabala, J., Zalewski, A. 2012. The impact of river fragmentation on the population persistence of native and alien mink: an ecological trap for the endangered European mink. Biodivers. Conserv. 22(1): 169-186. DO 10.1007/s10531-012-0410-3 